\title{
Novel Design and Thermodynamic Analyses of Cascade Refrigeration System at Ultra-Low Temperature
}

\author{
Hüsamettin $\operatorname{Tan}^{1 *}$, Ali Erişen ${ }^{2}$ \\ 1* Mechanical Engineering, Kırıkkale University, Yahşihan/Kırıkkale, 71450, Turkey \\ ${ }^{2}$ Institute of Scientific, Kırıkkale University, Yahşihan/Kırıkkale, 71450, Turkey \\ E-mail: ${ }^{1 *}$ husamettintan@ @otmail.com
}

Received 01 November 2021 , Revised 27 December 2021, Accepted 31 January 2022

\begin{abstract}
In this study, a cascade refrigeration system comprising gas and vapor compression cycles operating at ultra-low temperature was designed. In the thermodynamic analyses, R744, R404A, and R410A refrigerants in the high temperature cycle (HTC), and R1150, R170, and R23 in the low temperature cycle (LTC) were used. Thermodynamic analyses were carried out using the Engineering Equation Solver package program. Outputs considered were: system performance(COP), compression ratio, mass flow ratio and HTC cascade outlet temperature. Results show that, at different LTC condenser temperature values, R404A/R23 has the highest COP value, in the LTC, R23 has the highest compression ratio, while R1150 has the lowest one, in the HTC, R404A has the highest compression ratio, while R744 has the lowest one, the performance of the system increased with the decrease of the mass flow ratio.
\end{abstract}

Keywords: Ultra-low temperature; COP; cascade refrigeration; thermodynamic analyses; gas cycle; vapor compression cycle

\section{Introduction}

In refrigeration systems, energy consumption and the negative impact of the refrigerants on the environment are critical issues that need to be addressed. Refrigeration systems represent almost $17 \%$ of the global electrical energy consumption [1]. Considering that the available energy resources worldwide are limited and gradually decreasing, in the last 50 years, the improvement of refrigeration systems has become increasingly important. Moreover, environmental consciousness requires the evaluation of refrigerants in terms of ozone layer depletion (ODP) and global warming potential (GWP). The European Commission has introduced restrictions by approving the Fgas regulation for refrigerants [2]. The F-gas regulation restricts the implementation of hydrofluorocarbon (HFC) refrigerants based on their high GWP value. Since 2020, refrigerants having a GWP value of higher than 2500 have been generally restricted by F-gas regulation. However, these restrictions do not apply to military equipment and systems that function at temperatures below $-50{ }^{\circ} \mathrm{C}[3]$.

Refrigeration systems vary based on the application area and the required ambient temperature [4]-[9]. In applications such as in the petroleum, medical, or food industries, as well as for air conditioning systems, the ambient temperatures vary between $-150{ }^{\circ} \mathrm{C}$ and $5{ }^{\circ} \mathrm{C}$. Vapor compression refrigeration cycles have been widely used in refrigeration systems for many years [10]. When using single-stage vapor compression systems, low temperatures are difficult to obtain because of the system elements restriction. In addition, due to the low coefficient of performance (COP), single-stage vapor compression systems are not economically viable because of their high energy consumption. In industrial applications, the lowest ambient temperature that is possible to obtain is approximately -40 ${ }^{\circ} \mathrm{C}$ when using single-stage vapor compression systems [11]. Cascade refrigeration systems operating with two or more cycles provide ultra-low temperatures and a high COP. They comprise independent cycles that allow the use of different operating designs and refrigerants [12]-[18]. This studies on cascade refrigeration systems are aimed at increasing the COP. To achieve this, there are two different possible working areas: the use of alternative cycles and the use of an alternative refrigerant or refrigerant mixtures.

There are mainly four different cascade refrigeration system designs in the literature for the use of alternative cycles. These designs are two-stage vapor compression cascade refrigeration system (CCRS), vapor compression and absorption cascade refrigeration system (CACRS), twostage absorption cascade refrigeration system (CARS), and auto-cascade refrigeration system (ACRS)[19].

The studies conducted on the CCRS have mostly used the R717 / R744 refrigerant pair [20]-[27]. These studies have shown that high COP is obtained when using the R744 refrigerant in the low-temperature cycle (LTC) and the R717 refrigerant in the high-temperature cycle (HTC). In addition to these two refrigerants, thermodynamic analyses for hydrocarbon and HFC group refrigerants in the HTC, such as, R1270 [15], [28], [29], R600 [4], R290 [15], [29], [30], and R404A [29], [31], [32], and in the LTC, such as R41 [33], R170 [28], [34], R1150 [28], R23 [31], and $\mathrm{N}_{2} \mathrm{O}$ [28],[35] have already been conducted.

In all studies, pure refrigerants were used. Research has also been conducted using an ejector as an innovative design for two-stage vapor compression cycles for increasing the COP [5], [36]-[39]. 
Two-stage CARSs are systems in which $\mathrm{NH}_{3} / \mathrm{H}_{2} \mathrm{O}$ and $\mathrm{LiBr} / \mathrm{H}_{2} \mathrm{O}$ pairs are used to obtain low temperatures down to $-40{ }^{\circ} \mathrm{C}$ [19]. The use of $\mathrm{LiBr}$ is not suitable at ultra-low temperatures because it crystallizes. The use of CARS is preferred to reduce energy consumption. Limited research has been conducted on CARS because of their low COP. Researches are available in the literature for $\mathrm{LiBr}, \mathrm{LiCl}, \mathrm{NH}_{3}$, and $\mathrm{H}_{2} \mathrm{O}$ refrigerants [40]-[42]. Although low ambient temperatures are obtained using two-stage vapor compression cascade refrigeration systems, they are ineffective because they consume large amounts of electrical energy. In this case, CARS in the HTC and CCRS in the LTC are used. Previous studies analyzed CARS using $\mathrm{LiBr}, \mathrm{NH}_{3}$, and $\mathrm{H}_{2} \mathrm{O}$ refrigerants [42] and CCRS using R1234yf, R1234ze, $\mathrm{CO}_{2}, \mathrm{NH}_{3}, \mathrm{R} 410 \mathrm{~A}$, and R134a [42]-[48]. The operation and maintenance of cascade refrigeration system is high. Therefore, in recent years, Auto-cascade refrigerant system with mixed refrigerants driven by single compressor that has lower capital cost are widely used. There have been many researches to improve system performance(COP) in ACRS, including optimization of system parameters, selection of refrigerant and efficient cycle modification [49]-[56].

When analyzing the refrigeration cycles used in cascade refrigeration systems, the primary aim is to reach the desired ambient temperature with an effective COP. In this study, a cascade refrigeration system operating at ultra-low temperature using gas (high temperature) and vapor compression (low temperature) refrigeration cycles is designed, which has not yet been discussed in previous studies. The gas refrigeration cycle in cascade systems has never been investigated before. In all cases, the refrigerant is in a single phase state in the gas cycle. The gas refrigeration cycle in cascade systems has never been investigated before. In all cases, the refrigerant is in a single phase state in the gas cycle. The objectives of the study are to make a new system design contribution to the literature in terms of the refrigerant cycles used and the reduction of net energy consumption with the energy produced by the expansion element in the gas cycle. In the designed system, thermodynamic analyses were performed using R410A, R404A, and R744 refrigerants in the HTC and R23, R1150, and R170 refrigerants in the LTC. For the different refrigerant couples, coefficient of performances, compression ratio and mass flow ratio were investigated in the new designed system.

\section{Material and Method \\ 2.1 System Design}

Figure 1 illustrates the cascade refrigeration system wherein the designed gas and vapor compression cycles work together. Gas refrigeration cycle in the HTC and vapor compression refrigeration cycle in the LTC are used. These two cycles are connected via a cascade heat exchanger.

In the LTC, the saturated vapor phase refrigerant (\# 4) at the evaporator outlet enters the cascade heat exchanger by increasing its temperature and pressure with the LTC compressor (\# 1). In the cascade heat exchanger, heat is transferred from the LTC to the HTC at constant pressure, and the refrigerant enters the expansion valve (\# 2) as a saturated liquid, expanding at constant enthalpy and entering the evaporator as a saturated liquid-vapor mixture (\# 3). In the HTC, the pressure and temperature of the refrigerant at the cascade heat exchanger outlet (\# 8) is increased by the HTC compressor, and the refrigerant enters the cooler (\# 5). In the HTC gas cooler, the refrigerant, whose temperature decreases with the release of heat at constant pressure (\# 6), enters the cascade heat exchanger, and its pressure and temperature are reduced by the expander element (\# 7). There is a two-phase flow in the LTC and a single-phase flow in the HTC.

Low Temperature Cycle (LTC) High Temperature Cycle (HTC)

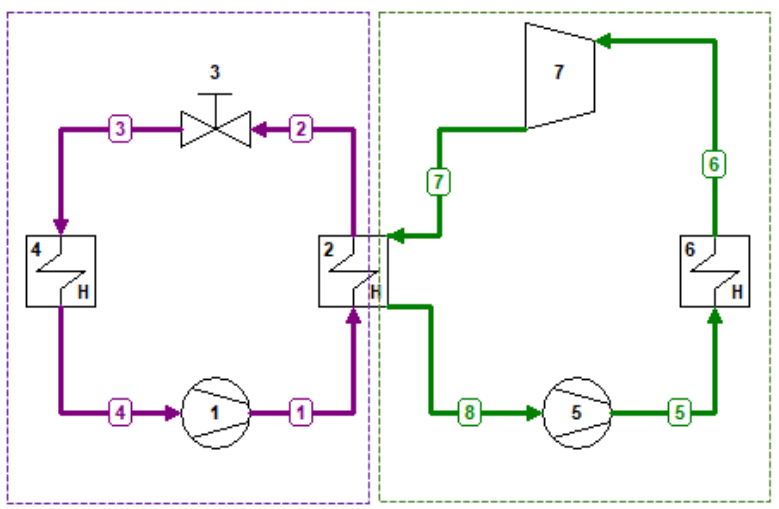

1- LTC Compressor, 2-Cascade Heat Exchanger, 3-Expansion Valve, 4-Evaporator,

5-HTC Compressor, 6-Gas Cooler, 7- Expander

Figure 1. Schematic of cascade refrigeration system.

\subsection{Modeling and Thermodynamic Analysis of the Cascade Refrigeration Cycle}

In the theoretical analyses of the designed system in terms of energy, the following assumptions have been made:

- All components are assumed to be in steady-state and steady-flow process;

- The potential and kinetic energy changes are negligible;

- Pressure losses in fittings and heat exchangers are negligible;

- In the LTC, the evaporator outlet is considered to be saturated vapor (\# 4) and the condenser outlet is considered to be saturated liquid (\# 2);

- The isentropic efficiency for both compressors and expander was fixed as $80 \%$; based on recommended values by [40];

- The expansion valves are isenthalpic devices;

- The evaporator working pressure is higher than the atmospheric pressure;

- In the thermodynamic analysis, the refrigeration capacity of the system is $1 \mathrm{~kW}$, the LTC evaporator temperature is $-80{ }^{\circ} \mathrm{C}\left(\mathrm{T}_{4}\right)$ and $\mathrm{HTC}$ expander outlet temperature is $42{ }^{\circ} \mathrm{C}\left(\mathrm{T}_{7}\right)$;

- LTC condenser temperature is in intervals of $1{ }^{\circ} \mathrm{C}$ ranging from $-35{ }^{\circ} \mathrm{C}$ to $-30{ }^{\circ} \mathrm{C}\left(\mathrm{T}_{2}\right)$, HTC cascade heat exchanger outlet temperature is changed according to getting the best COP $\left(\mathrm{T}_{8}\right)$, HTC gas cooler outlet temperature $20{ }^{\circ} \mathrm{C}\left(\mathrm{T}_{6}\right)$.

According to the balance of mass and energy, the thermodynamic analyzes of system are carried out for steady-state process. Energy analyzes are made for all system elements based on Equations (1) and (2). As a result of energy analyzes, the equations of the system elements are given in the below.

Mass balance;

$\sum \dot{m}_{g}=\sum \dot{m}_{\mathrm{c}}$

Energy balance;

$\sum \dot{Q}_{n e t}+\sum W_{n e t}+\sum \dot{m}\left(h_{g}-h_{c}\right)=0$ 
Table 1. Properties of refrigerant fluid.

\begin{tabular}{cccccc}
\hline Cycle & Refrigerant & Boiling Point, ${ }^{\mathbf{0}} \mathbf{C}$ & $\begin{array}{c}\text { Critical } \\
\text { Temperature, }{ }^{\mathbf{0}} \mathbf{C}\end{array}$ & $\begin{array}{c}\text { Critical } \\
\text { Pressure, bar }\end{array}$ & GWP \\
\hline \multirow{2}{*}{ HTC } & R744(HC) & -78.464 & 30.978 & 73.77 & 1 \\
& R404A (HFC) & -46.5 & 72 & 37.29 & 3260 \\
& R410A (HFC) & -51.5 & 71.8 & 49.01 & 2088 \\
\hline \multirow{2}{*}{ LTC } & R23 (HFC) & -81.87 & 26.29 & 48.32 & 14800 \\
& R170 (HC) & -88.584 & 32.172 & 48.72 & 6 \\
& R1150 (HC) & -103.77 & 9.2 & 50.41 & 4 \\
\hline
\end{tabular}

Energy balance across the evaporator is given by:

$\dot{Q}_{\text {evap }}=\dot{m}_{L T C} \cdot\left(h_{4}-h_{3}\right)$

The isentropic efficiency for LTC compressor is given by:

$\eta_{C_{-} L T C}=\frac{h_{1 s}-h_{4}}{h_{1}-h_{4}}$

The power input to the LTC compressor is given by:

$\dot{W}_{L T C}=\dot{m}_{L T C} \cdot\left(h_{1}-h_{4}\right)$

The energy balance across the cascade heat exchanger is given by:

$\dot{m}_{L T C} \cdot\left(h_{1}-h_{2}\right)=\dot{m}_{H T C} \cdot\left(h_{8}-h_{7}\right)$

The isentropic efficiency for HTC compressor is given by:

$\eta_{C_{-} H T C}=\frac{h_{5 s}-h_{8}}{h_{5}-h_{8}}$

The power input to the HTC compressor is given by:

$\dot{W}_{H T C}=\dot{m}_{H T C} \cdot\left(h_{5}-h_{8}\right)$

The energy balance across the gas cooler is given by:

$\dot{Q}_{g a s}=\dot{m}_{H T C} \cdot\left(h_{6}-h_{5}\right)$

The isentropic efficiency for expander is given by:

$\eta_{E X P}=\frac{h_{6}-h_{7}}{h_{6 s}-h_{7}}$

The power output to the expander is given by:

$\dot{W}_{E X P}=\dot{m}_{H T C} \cdot\left(h_{6}-h_{7}\right)$

The COP of the system, which is the main parameter to be calculated for the energy analysis, is obtained using Equation 12. Here, $\dot{Q}_{\text {evap }}$ is the evaporator refrigeration capacity in the LTC, $\dot{W}_{L T C}$ is the compressor power in the LTC, $\dot{W}_{H T C}$ is the compressor power in the HTC, $\dot{W}_{E X P}$ is the power generated during expansion in the HTC.

$C O P_{\text {system }}=\frac{\dot{Q}_{\text {evap }}}{\dot{W}_{L T C}+\dot{W}_{H T C}-\dot{W}_{E X P}}$

The COP was calculated using the Engineering Equation Solver (EES) package program using the energy equations[58]. EES provides many built-in mathematical and thermophysical property functions useful for engineering calculations. Many researchers used the EES for thermodynamic modeling of refrigeration systems [12], [20], [21], [25], [43], [59]-[63]. In the thermodynamic analysis, R744, R404A, and R410A refrigerants in the high temperature cycle (HTC), and R1150, R170, and R23 in the low temperature cycle (LTC) were used. In the selection of refrigerants, R23, R1150 and R170 were selected when their boiling point temperatures were considered in order to provide $-80^{\circ} \mathrm{C}$ refrigerant temperature in the low temperature cycle. Refrigerants selections in the high temperature cycle are environmentally friendly and widely used, so R744. Since R404A and R410A are widely used, it has also been observed that the boiling temperature decreases to $-42{ }^{\circ} \mathrm{C}$ at 1 atm pressure. Otherwise, a situation below atmospheric pressure is not be desired in the system. The thermodynamic properties of the refrigerants used from the library in the EES. The main properties of the selected refrigerants are presented in Table 1.

\section{Results and Discussion}

Under the assumptions, thermodynamic analyses were conducted for refrigerant couples in the cascade refrigeration system. COPs of refrigerant couples, compression ratio of compressors and net energy consumption values of system were determined. According to these parameters, the best refrigerant couple among them selected.

Figure 2 shows the change in the COPs of refrigerant couples with respect to the LTC condenser temperature. In this figure, LTC evaporator, HTC gas cooler outlet and HTC expander outlet temperature are kept constant at $-80^{\circ} \mathrm{C}, 20^{\circ}$ and $-42^{\circ} \mathrm{C}$, respectively. At different LTC condenser temperature values, HTC cascade heat exchanger outlet temperature has been determined to maximize system performance (COP). COPs for refrigerant couples increases with increasing LTC condenser temperature as shown in Figure 2. In the determined LTC condenser temperature range, R404A/R23 has the highest COP value, while R744/R170 has the lowest one. R404A/R1150 can be considered as an alternative for R404A/R23 because the COP of R404A/R1150 is very close that of R404A/R23.

Figure $3 \mathrm{a}$ shows the change in the compression ratio of refrigerant in LTC with respect to the LTC condenser temperature. In this figure, HTC compression ratio is kept constant at 3.6 for R744 in HTC. Among the different fluids in the low temperature cycle, R23 has the highest compression ratio, while R1150 has the lowest one. Figure $3 \mathrm{~b}$ shows the compression ratio of HTC refrigerants. In this figure, HTC expander outlet and gas cooler outlet temperature are kept at constant at $-42^{\circ} \mathrm{C}$ and $20^{\circ} \mathrm{C}$, respectively. Therefore, compression ratio of $\mathrm{HTC}$ is 
constant for all LTC refrigerants. Among the different fluids in the HTC, R404A has the highest compression ratio, while R744 has the lowest one.

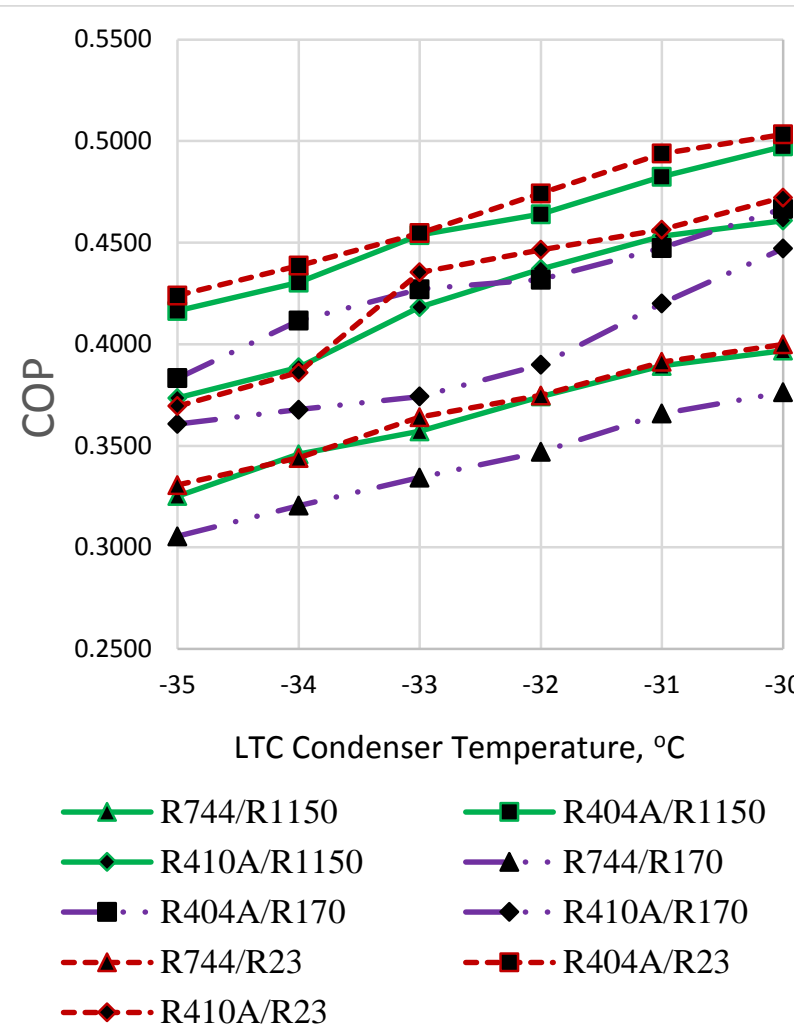

Figure 2. COPs of refrigerant couples as a function of LTC condenser temperature.

The relation between HTC cascade heat exchanger and LTC compressor outlet temperatures is presented in Table 2, Table 3 and Table 4 for all refrigerant couples. Increasing the LTC compressor outlet temperature allows the HTC cascade heat exchanger outlet temperature to increase. As the HTC cascade heat exchanger outlet temperature increases, the mass flow ratio decreases between LTC and HTC. The performance of the system increased with the decrease of the mass flow ratio. Because, energy consumption value of the compressor in the high temperature cycle has decreased.

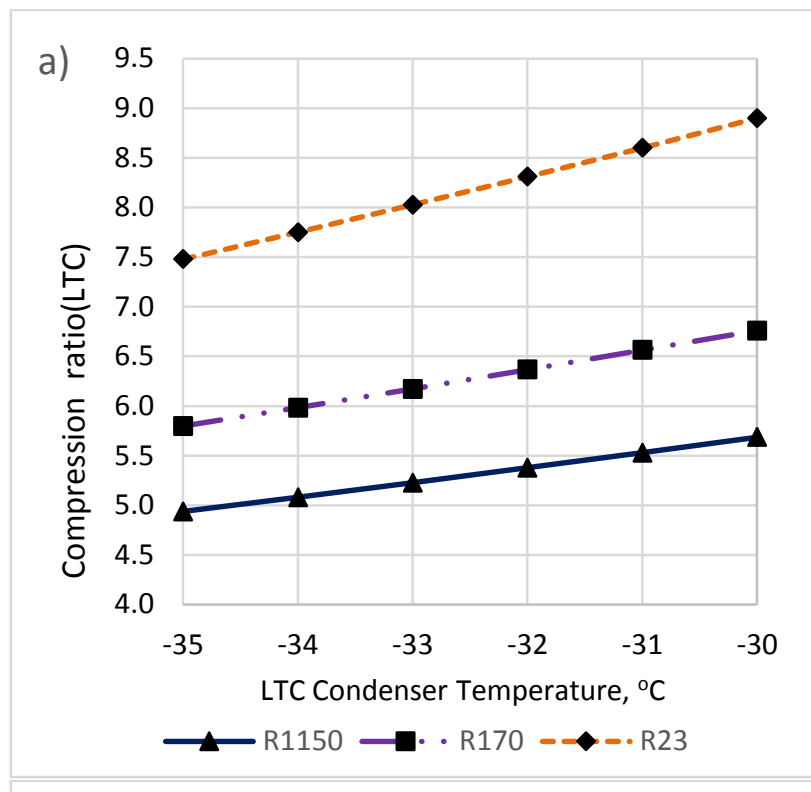

b)

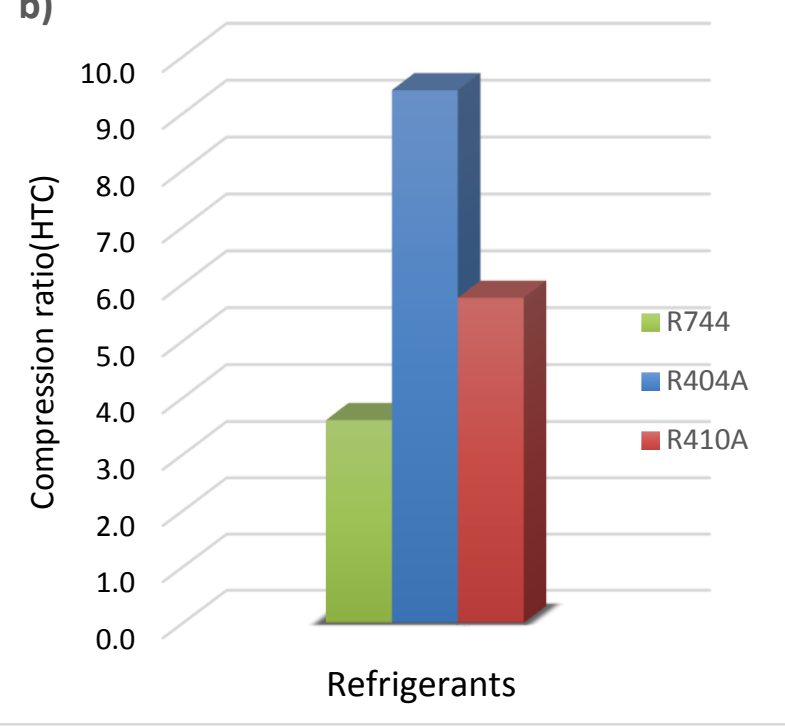

Figure 3. Compression ratio a) LTC refrigerants b) HTC refrigerants.

Table 2. Relation between HTC cascade heat exchanger outlet and LTC compressor outlet temperature for R1150 in LTC.

\begin{tabular}{cccccc}
\hline $\begin{array}{c}\text { Refrigerant } \\
\text { Couples }\end{array}$ & $\begin{array}{c}\text { LTC Condenser } \\
\text { Temperature }\end{array}$ & $\begin{array}{c}\text { HTC Cascade } \\
\text { Heat Ex. } \\
\text { Outlet } \\
\text { Temperature }\end{array}$ & $\begin{array}{c}\text { LTC Compressor } \\
\text { Outlet } \\
\text { Temperature }\end{array}$ & $\begin{array}{c}\text { Mass Flow } \\
\text { Ratio } \\
\text { (LTC/HTC) }\end{array}$ & COP \\
\hline R744/R1150 & -30 & -3 & 32,65 & 13,94 & 0,3969 \\
R404A/R1150 & -30 & -3 & 32,65 & 14,09 & 0,4974 \\
R410A/R1150 & -30 & -4 & 32,65 & 14,55 & 0,4609 \\
\hline R744/R1150 & -31 & -5 & 30,66 & 14,75 & 0,3894 \\
R404A/R1150 & -31 & -6 & 30,66 & 15,38 & 0,4825 \\
R410A/R1150 & -31 & -6 & 30,66 & 15,40 & 0,4532 \\
\hline R744/R1150 & -32 & -8 & 28,65 & 15,93 & 0,3743 \\
R404A/R1150 & -32 & -9 & 28,65 & 16,65 & 0,464 \\
R410A/R1150 & -32 & -9 & 28,65 & 16,66 & 0,437 \\
\hline R744/R1150 & -33 & -11 & 26,63 & 17,31 & 0,3571 \\
R404A/R1150 & -33 & -11 & 26,63 & 18,12 & 0,4538 \\
R410A/R1150 & -33 & -12 & 26,63 & 18,74 & 0,4183 \\
\hline R744/R1150 & -34 & -13 & 24,61 & 18,93 & 0,3459 \\
R404A/R1150 & -34 & -14 & 24,61 & 19,96 & 0,4304 \\
R410A/R1150 & -34 & -16 & 24,61 & 21,38 & 0,3886 \\
\hline R744/R1150 & -35 & -16 & 22,57 & 20,93 & 0,3253 \\
R404A/R1150 & -35 & -16 & 22,57 & 21,48 & 0,4165 \\
R410A/R1150 & -35 & -18 & 22,57 & 22,93 & 0,3736 \\
\hline
\end{tabular}


Table 3. Relation between HTC cascade heat exchanger outlet and LTC compressor outlet temperature for R170 in LTC.

\begin{tabular}{cccccc}
\hline $\begin{array}{c}\text { Refrigerant } \\
\text { Couples }\end{array}$ & $\begin{array}{c}\text { LTC Condenser } \\
\text { Temperature }\end{array}$ & $\begin{array}{c}\text { HTC Cascade } \\
\text { Heat Ex. } \\
\text { Outlet } \\
\text { Temperature }\end{array}$ & $\begin{array}{c}\text { LTC Compressor } \\
\text { Outlet } \\
\text { Temperature }\end{array}$ & $\begin{array}{c}\text { Mass Flow } \\
\text { Ratio } \\
\text { (LTC/HTC) }\end{array}$ & COP \\
\hline R744/R170 & -30 & -8 & 22,29 & 17.50 & 0,3763 \\
R404A/R170 & -30 & -9 & 22,29 & 18,30 & 0,4667 \\
R410A/R170 & -30 & -8 & 22,29 & 17,77 & 0,4471 \\
\hline R744/R170 & -31 & -10 & 20,53 & 18,44 & 0,3659 \\
R404A/R170 & -31 & -12 & 20,53 & 19,96 & 0,4474 \\
R410A/R170 & -31 & -12 & 20,53 & 19,97 & 0,4202 \\
\hline R744/R170 & -32 & -13 & 18,76 & 20,20 & 0,347 \\
R404A/R170 & -32 & -14 & 18,76 & 21,27 & 0,4318 \\
R410A/R170 & -32 & -16 & 18,76 & 22,79 & 0,3899 \\
\hline R744/R170 & -33 & -15 & 16,98 & 22,28 & 0,3344 \\
R404A/R170 & -33 & -15 & 16,98 & 22,67 & 0,4271 \\
R410A/R170 & -33 & -18 & 16,98 & 25,36 & 0,3743 \\
\hline R744/R170 & -34 & -17 & 15,19 & 23,89 & 0,3205 \\
R404A/R170 & -34 & -17 & 15,19 & 24,29 & 0,4117 \\
R410A/R170 & -34 & -19 & 15,19 & 26,25 & 0,3678 \\
\hline R744/R170 & -35 & -19 & 13,38 & 25,75 & 0,3055 \\
R404A/R170 & -35 & -20 & 13,38 & 27,36 & 0,3833 \\
R410A/R170 & -35 & -20 & 13,38 & 27,21 & 0,3608 \\
\hline
\end{tabular}

Table 4. Relation between HTC cascade heat exchanger outlet and LTC compressor outlet temperature for R23 in LTC.

\begin{tabular}{cccccc}
\hline $\begin{array}{c}\text { Refrigerant } \\
\text { Couples }\end{array}$ & $\begin{array}{c}\text { LTC Condenser } \\
\text { Temperature }\end{array}$ & $\begin{array}{c}\text { HTC Cascade } \\
\text { Heat Ex. } \\
\text { Outlet } \\
\text { Temperature }\end{array}$ & $\begin{array}{c}\text { LTC Compressor } \\
\text { Outlet } \\
\text { Temperature }\end{array}$ & $\begin{array}{c}\text { Mass Flow } \\
\text { Ratio } \\
\text { (LTC/HTC) }\end{array}$ & COP \\
\hline R744/R23 & -30 & -4 & 36,45 & 7,84 & 0,399 \\
R404A/R23 & -30 & -4 & 36,45 & 7,92 & 0,5033 \\
R410A/R23 & -30 & -4 & 36,45 & 7,97 & 0,4722 \\
\hline R744/R23 & -31 & -6 & 34,42 & 8,24 & 0,3913 \\
R404A/R23 & -31 & -6 & 34,42 & 8,34 & 0,4939 \\
R410A/R23 & -31 & -7 & 34,42 & 8,60 & 0,4564 \\
\hline R744/R23 & -32 & -9 & 32,39 & 9,07 & 0,3748 \\
R404A/R23 & -32 & -9 & 32,39 & 9,21 & 0,4743 \\
R410A/R23 & -32 & -9 & 32,39 & 9,21 & 0,4465 \\
\hline R744/R23 & -33 & -11 & 30,35 & 9,58 & 0,3642 \\
R404A/R23 & -33 & -12 & 30,35 & 10,04 & 0,4547 \\
R410A/R23 & -33 & -11 & 30,35 & 9,72 & 0,4354 \\
\hline R744/R23 & -34 & -14 & 28,29 & 10,71 & 0,344 \\
R404A/R23 & -34 & -14 & 28,29 & 10,91 & 0,4387 \\
R410A/R23 & -34 & -17 & 28,29 & 12,14 & 0,3861 \\
\hline R744/R23 & -35 & -16 & 26,22 & 11,44 & 0,3308 \\
R404A/R23 & -35 & -16 & 26,22 & 11,64 & 0,424 \\
R410A/R23 & -35 & -19 & 26,22 & 13,07 & 0,3696 \\
\hline
\end{tabular}

\section{Conclusions}

In this study, a new cascade system was designed for a refrigeration system operating at ultra-low temperatures, consisting of two cycles, namely HTC by gas and LTC by vapor compression. Thermodynamic analysis of the system in terms of the energy performance was performed. In order to determine the best refrigerant couples in terms of the COP, R1150, R170, and R23 refrigerants in the LTC and R404A, $\mathrm{R} 410 \mathrm{~A}$, and R744 refrigerants in the HTC were analyzed. LTC condenser temperature was considered as a variable parameter in the system. HTC cascade heat exchanger inlet temperature is constant and the outlet temperature is changed in each condition. The primary results of the study are listed below:

- Among the different refrigerants analyzed, the R404A / $\mathrm{R} 23$ refrigerant couple has the best result in terms of the COP while R744/R170 has the lowest one. (Figure 2):

- R23 has high vapor density and low condensing pressure at design temperatures in the LTC. These properties reduce the compressor energy consumption in the LTC. The high temperature value at the compressor outlet increases the HTC outlet temperature in the cascade heat exchanger. Increasing the enthalpy difference between the inlet and outlet of the HTC cascade heat exchanger reduces the mass flow rate. The decrease in HTC mass flow rate increases the system performance by reducing HTC net energy consumption. Among the refrigerants (R744, R410A), R404A has the highest vapor density at operating conditions in HTC. In this case, the HTC compressor has the lowest specific volume at its inlet, thereby increasing the system performance by reducing energy consumption.

- R744 has low vapor density at design temperature. In this case, the high specific volume at the compressor inlet increases the energy consumption value. The vapor density of R170 is low at design temperature. Again, this situation increases the energy consumption value due to the high specific volume of compressor inlet. In addition, when compared to other refrigerants at the compressor outlet in the low-temperature cycle, the low-temperature value reduces the outlet temperature in the hightemperature cycle cascade heat exchanger. The decrease in the HTC cascade heat exchanger outlet temperature increased the HTC mass flow rate. For this reason, HTC net energy consumption value increased and decreased the system performance.

- Compression ratios of refrigerants vary according to the lower and upper pressure values at operating 
temperatures. Among the operating temperatures for the low temperature cycle, the upper and lower pressure ratio is highest for R23 and lowest for R1150. For high temperature cycle, between $-42^{\circ} \mathrm{C}$ and $20^{\circ} \mathrm{C}$, the upper and lower pressure ratio is the highest for R404A and the lowest for R744.

- With the increase of LTC condenser temperature, system performance (COP) values increased for all refrigerant couples.

- As the HTC cascade heat exchanger outlet temperature increases, the mass flow ratio decreases between LTC and HTC and the performance of the system increased. It is an important parameter for the best value of system performance (COP).

- The higher the mass flow ratio between the gas and vapor compression cycles, the lower the temperature difference between the HTC cascade heat exchanger inlet and outlet. In this case, the high mass flow rate on the gas cycle increases the energy consumption and has a negative effect on the system performance (COP).

- The energy consumption value of the HTC compressor is more effective than the energy consumption of the LTC compressor in determining the system performance.

It is seen that the system performance (COP) values are not at a satisfactory level according to the results in the literature. It is necessary to take into account the negative situations that arise as a result of using gas and vapor compression cycles together. In the study, a novel design idea has contributed to the literature in terms of cascade systems designs. In future studies, the results of the thermodynamic analysis of the design will give an idea to the researchers. Before making this design experimentally, it has been determined that theoretical studies should be carried out in order to eliminate the problems that cause the system performance to be low in thermodynamic analyzes.

$\begin{array}{ll}\text { Nomenclature } \\ \dot{m} & \text { Mass flow rate }(\mathrm{kg} / \mathrm{s}) \\ \mathrm{h} & \text { Enthalpy }(\mathrm{kJ} / \mathrm{kg}) \\ \dot{\mathrm{W}} & \text { Energy consumption }(\mathrm{kW}) \\ \dot{Q} & \text { Heat rate }(\mathrm{kW})\end{array}$

\section{Greek Letters}

$\eta \quad$ Isentropic efficiency (-)

\section{Subscriptions \\ gas gas cooler \\ EXP expander \\ evap evaporator}
Abbreviations
LTC Low temperature cycle
HTC High temperature cycle
COP Coefficient of performance
EES Engineering Equation Solver
ODP Ozone layer depletion
GWP Global warming potential
HFC Hydrofluorocarbon
CCRS Two-stage vapor compression cascade refrigeration system
CACRS Vapor compression and absorption cascade refrigeration system
CARS Two-stage absorption cascade refrigeration system
ACRS Auto-cascade refrigeration system

\section{References:}

[1] IIR, "The Role of Refrigeration in the Global Economy," 2015.[Online].Available:https://www.scribd.com/docum ent/452307076/NoteTech-29-EN-2-pdf.

[2] European Commission, "Regulation (EU) No 517/2014 of The European Parliament and of the council of 16 April 2014 on fluorinated greenhouse gases and repealing Regulation (EC) No 842/2006," 2014.

[3] A.Mota-Babiloni et al., "Ultralow-temperature refrigeration systems: Configurations and refrigerants to reduce the environmental impact,"Int.J.Refrig., vol.111,pp.147-158,Mar.2020,doi: 10.1016/J.IJREFRIG.2019.11.016.

[4] H. Yamaguchi, X.-D. Niu, K. Sekimoto, and P. Nekså, "Investigation of dry ice blockage in an ultra-low temperature cascade refrigeration system using $\mathrm{CO} 2$ as a working fluid," Int. J. Refrig., vol. 34, no. 2, pp. 466-475, Mar. 2011, doi: 10.1016/J.IJREFRIG.2010.11.001.

[5] K. Megdouli, B. M. Tashtoush, E. Nahdi, M. Elakhdar, L. Kairouani, and A. Mhimid, "Thermodynamic analysis of a novel ejector-cascade refrigeration cycles for freezing process applications and air-conditioning," Int. J. Refrig., vol. 70, pp. 108-118, Oct. 2016, doi: 10.1016/J.IJREFRIG.2016.06.029.

[6] J. Lee, C. Lee, S. Baek, and S. Jeong, "Investigation of ejector-equipped Joule-Thomson refrigerator operating below 77 K," Int. J. Refrig., vol. 78, pp. 93-107, Jun. 2017, doi: 10.1016/J.IJREFRIG.2017.03.016.

[7] H. C. Wang, G. F. Chen, X. Q. Dong, Y. X. Zhao, H. Guo, and M. Q. Gong, "Performance comparison of single-stage mixed-refrigerant Joule-Thomson cycle and pure-gas reverse Brayton cycle at fixed-temperatures from 80 to $180 \mathrm{~K}$," Int. J. Refrig., vol. 80, pp. 77-91, Aug. 2017, doi: 10.1016/J.IJREFRIG.2017.05.011.

[8] A. Biglia et al., "Reversed Brayton cycle for food freezing at very low temperatures: Energy performance and optimisation," Int. J. Refrig., vol. 81, pp. 82-95, Sep. 2017, doi: 10.1016/J.IJREFRIG.2017.05.022.

[9] Z. Hongli, H. Yu, and C. Liang, "Experimental study on a small Brayton air refrigerator under $-120{ }^{\circ} \mathrm{C}$," Appl. Therm. Eng., vol. 29, no. 8-9, pp. 1702-1706, Jun. 2009, doi: 10.1016/J.APPLTHERMALENG.2008.07.028.

[10] L. H. P. Massuchetto, R. B. C. do Nascimento, S. M. R. de Carvalho, H. V. de Araújo, and J. V. H. d'Angelo, "Thermodynamic performance evaluation of a cascade refrigeration system with mixed refrigerants: R744/R1270, R744/R717 and R744/RE170," Int. J. Refrig., vol. 106, pp. 201-212, Oct. 2019, doi: 10.1016/J.IJREFRIG.2019.07.005.

[11] D. Yılmaz, Ü. Sınar, A. Özyurt, B. Y1lmaz, and E. Mancuhan, "Numerical Investigation of Performance Effects of Excessive Cooling and Heating in a Two-Stage Cooling System Operating at Ultra Low Temperatures," Afyon Kocatepe Univ. J. Sci. Eng., vol. 17, pp. 11721180, 2017, doi: 10.5578/fmbd.66304.

[12] A. M. Dubey, S. Kumar, and G. Das Agrawal, "Thermodynamic analysis of a transcritical CO2/propylene (R744-R1270) cascade system for cooling and heating applications," Energy Convers. 
Manag., vol. $\quad 86$, pp. 774-783, 2014, doi: 10.1016/j.enconman.2014.05.105.

[13] P. Bansal, "A review - Status of CO 2 as a low temperature refrigerant: Fundamentals and R\&D opportunities," Appl. Therm. Eng., vol. 41, pp. 18-29, 2012, doi: 10.1016/j.applthermaleng.2011.12.006.

[14] B. Niu and Y. Zhang, "Experimental study of the refrigeration cycle performance for the R744/R290 mixtures," Int. J. Refrig., vol. 30, no. 1, pp. 37-42, Jan. 2007, doi: 10.1016/J.IJREFRIG.2006.06.002.

[15] K. K. Singh, R. Kumar, and A. Gupta, "Multi-objective Optimization of Thermodynamic and Economic Performances of Natural Refrigerants for Cascade Refrigeration," Arab. J. Sci. Eng., vol. 46, no. 12, pp. 12235-12252, 2021, doi: 10.1007/s13369-021-05924-w.

[16] Y. D. Zhu, Z. R. Peng, G. B. Wang, and X. R. Zhang, "Thermodynamic analysis of a novel multi-targettemperature cascade cycle for refrigeration," Energy Convers. Manag., vol. 243, no. March, p. 114380, 2021, doi: 10.1016/j.enconman.2021.114380.

[17] V. Adebayo, M. Abid, M. Adedeji, M. Dagbasi, and O. Bamisile, "Comparative thermodynamic performance analysis of a cascade refrigeration system with new refrigerants paired with CO2," Appl. Therm. Eng., vol. 184, p. 116286, 2021, doi: 10.1016/j.applthermaleng.2020.116286.

[18] K. Golbaten Mofrad, S. Zandi, G. Salehi, and M. H. Khoshgoftar Manesh, "4E analyses and multi-objective optimization of cascade refrigeration cycles with heat recovery system," Therm. Sci. Eng. Prog., vol. 19, p. 100613, 2020, doi: 10.1016/j.tsep.2020.100613.

[19] M. Pan, H. Zhao, D. Liang, Y. Zhu, Y. Liang, and G. Bao, "A review of the cascade refrigeration system," Energies, vol. 13, no. 9, 2020, doi: 10.3390/en13092254.

[20] E. Gholamian, P. Hanafizadeh, and P. Ahmadi, "Advanced exergy analysis of a carbon dioxide ammonia cascade refrigeration system," Appl. Therm. Eng., vol. 137, no. October 2017, pp. 689-699, 2018, doi: 10.1016/j.applthermaleng.2018.03.055.

[21] A. H. Mosaffa, L. G. Farshi, C. A. Infante Ferreira, and M. A. Rosen, "Exergoeconomic and environmental analyses of $\mathrm{CO} 2 / \mathrm{NH} 3$ cascade refrigeration systems equipped with different types of flash tank intercoolers," Energy Convers. Manag., vol. 117, pp. 442-453, 2016, doi: 10.1016/j.enconman.2016.03.053.

[22] M. Aminyavari, B. Najafi, A. Shirazi, and F. Rinaldi, "Exergetic, economic and environmental (3E) analyses, and multi-objective optimization of a CO2/NH3 cascade refrigeration system," Appl. Therm. Eng., vol. 65, no. 12, pp. 42-50, 2014, doi: 10.1016/j.applthermaleng.2013.12.075.

[23] J. Alberto Dopazo, J. Fernández-Seara, J. Sieres, and F. J. Uhía, "Theoretical analysis of a $\mathrm{CO} 2-\mathrm{NH} 3$ cascade refrigeration system for cooling applications at low temperatures," Appl. Therm. Eng., vol. 29, no. 8-9, pp. 1577-1583, 2009, 10.1016/j.applthermaleng.2008.07.006.

[24] W. Bingming, W. Huagen, L. Jianfeng, and X. Ziwen, "Experimental investigation on the performance of
$\mathrm{NH} 3 / \mathrm{CO} 2$ cascade refrigeration system with twin-screw compressor," Int. J. Refrig., vol. 32, no. 6, pp. 1358 1365, 2009, doi: 10.1016/j.ijrefrig.2009.03.008.

[25] H. M. Getu and P. K. Bansal, "Thermodynamic analysis of an R744-R717 cascade refrigeration system," Int. J. Refrig., vol. 31, no. 1, pp. 45-54, 2008, doi: 10.1016/j.ijrefrig.2007.06.014.

[26] T. S. Lee, C. H. Liu, and T. W. Chen, "Thermodynamic analysis of optimal condensing temperature of cascadecondenser in $\mathrm{CO} 2 / \mathrm{NH} 3$ cascade refrigeration systems," Int. J. Refrig., vol. 29, no. 7, pp. 1100-1108, 2006, doi: 10.1016/j.ijrefrig.2006.03.003.

[27] G. Di Nicola, G. Giuliani, F. Polonara, and R. Stryjek, "Blends of carbon dioxide and HFCs as working fluids for the low-temperature circuit in cascade refrigerating systems," Int. J. Refrig., vol. 28, no. 2, pp. 130-140, 2005, doi: 10.1016/j.ijrefrig.2004.06.014.

[28] J. Sarkar, S. Bhattacharyya, and A. Lal, "Performance comparison of natural refrigerants based cascade systems for ultra-low-temperature applications," Int. J. Sustain. Energy, vol. 32, no. 5, pp. 406-420, 2013, doi: 10.1080/14786451.2013.765426.

[29] G. Sachdeva, V. Jain, and S. S. Kachhwaha, "Performance Study of Cascade Refrigeration System Using Alternative Refrigerants," Int. J. Mech. Aerospace, Ind. Mechatron. Manuf. Eng., vol. 8, no. 3, p. 7, 2014, [Online].

Available: http://waset.org/publications/9997619/performancestudy-of-cascade-refrigeration-system-using-alternativerefrigerants.

[30] Nasruddin, S. Sholahudin, N. Giannetti, and Arnas, "Optimization of a cascade refrigeration system using refrigerant $\mathrm{C} 3 \mathrm{H} 8$ in high temperature circuits (HTC) and a mixture of $\mathrm{C} 2 \mathrm{H} 6 / \mathrm{CO} 2$ in low temperature circuits (LTC)," Appl. Therm. Eng., vol. 104, pp. 96-103, 2016, doi: 10.1016/j.applthermaleng.2016.05.059.

[31] A. Kilicarslan and M. Hosoz, "Energy and irreversibility analysis of a cascade refrigeration system for various refrigerant couples," Energy Convers. Manag., vol. 51, no. 12, pp. 2947-2954, 2010, doi: 10.1016/j.enconman.2010.06.037.

[32] R. Roy and B. K. Mandal, "Thermo-economic analysis and multi-objective optimization of vapour cascade refrigeration system using different refrigerant combinations: A comparative study," J. Therm. Anal. Calorim., vol. 139, no. 5, pp. 3247-3261, 2020, doi: 10.1007/s10973-019-08710-x.

[33] M. Deymi-Dashtebayaz, A. Sulin, T. Ryabova, I. Sankina, M. Farahnak, and R. Nazeri, "Energy, exergoeconomic and environmental optimization of a cascade refrigeration system using different low GWP refrigerants," J. Environ. Chem. Eng., vol. 9, no. 6, p. 106473, 2021, doi: 10.1016/j.jece.2021.106473.

[34] M. Gong, Z. Sun, J. Wu, Y. Zhang, C. Meng, and Y. Zhou, "Performance of R170 mixtures as refrigerants for refrigeration at $-80{ }^{\circ} \mathrm{C}$ temperature range," Int. J. Refrig., vol. 32, no. 5, pp. 892-900, 2009, doi: 10.1016/j.ijrefrig.2008.11.007.

[35] S. Bhattacharyya, A. Garai, and J. Sarkar, 
"Thermodynamic analysis and optimization of a novel N2O-CO2 cascade system for refrigeration and heating," Int. J. Refrig., vol. 32, no. 5, pp. 1077-1084, 2009, doi: 10.1016/j.ijrefrig.2008.09.008.

[36] HAN XINGWANG, "Super low temperature transcritical cascade refrigeration system and refrigeration method," CN110887266A, 2020.

[37] G. Chen, V. Ierin, O. Volovyk, and K. Shestopalov, “An improved cascade mechanical compression-ejector cooling cycle," Energy, vol. 170, pp. 459-470, Mar. 2019, doi: 10.1016/J.ENERGY.2018.12.107.

[38] R. Ben Mansour, M. Ouzzane, and Z. Aidoun, "Numerical evaluation of ejector-assisted mechanical compression systems for refrigeration applications," Int. J. Refrig., vol. 43, pp. 36-49, Jul. 2014, doi: 10.1016/J.IJREFRIG.2014.04.010.

[39] T. K. Nguyen and C. H. Le, "Thermodynamic analysis of an ejector-vapour compressor cascade refrigeration system," J. Therm. Anal. Calorim., vol. 141, no. 6, pp. 2189-2200, 2020, doi: 10.1007/s10973-020-09635-6.

[40] X. She, Y. Yin, M. Xu, and X. Zhang, "A novel lowgrade heat-driven absorption refrigeration system with LiCl-H2O and LiBr-H2O working pairs," Int. J. Refrig., vol. 58, pp. 219-234, 2015, doi: 10.1016/j.ijrefrig.2015.06.016.

[41] A. K. Songara, M. Fatouh, and S. Srinivasa Murthy, "Thermodynamic studies on HFC134a-DMA double effect and cascaded absorption refrigeration systems," Int. J. Energy Res., vol. 22, no. 7, pp. 603-614, 1998, doi: 10.1002/(SICI)1099-114X(19980610)22:7<603::AIDER379>3.0.CO;2-9.

[42] P. Cui, M. Yu, Z. Liu, Z. Zhu, and S. Yang, "Energy, exergy, and economic (3E) analyses and multi-objective optimization of a cascade absorption refrigeration system for low-grade waste heat recovery," Energy Convers. Manag., vol. 184, no. January, pp. 249-261, 2019, doi: 10.1016/j.enconman.2019.01.047.

[43] V. Jain, S. S. Kachhwaha, and G. Sachdeva, "Thermodynamic performance analysis of a vapor compression-absorption cascaded refrigeration system," Energy Convers. Manag., vol. 75, pp. 685-700, 2013, doi: 10.1016/j.enconman.2013.08.024.

[44] Y. Xu, F. S. Chen, Q. Wang, X. Han, D. Li, and G. Chen, "A novel low-temperature absorptioncompression cascade refrigeration system," Appl. Therm. Eng., vol. 75, pp. 504-512, 2015, doi: 10.1016/j.applthermaleng.2014.10.043.

[45] H. He, L. Wang, J. Yuan, Z. Wang, W. Fu, and K. Liang, "Performance evaluation of solar absorptioncompression cascade refrigeration system with an integrated air-cooled compression cycle," Energy Convers. Manag., vol. 201, no. September, p. 112153, 2019, doi: 10.1016/j.enconman.2019.112153.

[46] Z. Sun, C. Wang, Y. Liang, H. Sun, S. Liu, and B. Dai, "Theoretical study on a novel CO2 Two-stage compression refrigeration system with parallel compression and solar absorption partial cascade refrigeration system," Energy Convers. Manag., vol. 204, no. August 2019, p. 112278, 2020, doi: 10.1016/j.enconman.2019.112278.

[47] J. Fernández-Seara, J. Sieres, and M. Vázquez, "Compression-absorption cascade refrigeration system," Appl. Therm. Eng., vol. 26, no. 5-6, pp. 502-512, 2006, doi: 10.1016/j.applthermaleng.2005.07.015.

[48] Y. Xu, G. Chen, Q. Wang, X. Han, N. Jiang, and S. Deng, "Performance study on a low-temperature absorption-compression cascade refrigeration system driven by low-grade heat," Energy Convers. Manag., vol. 119, pp. 379-388, 2016, doi: 10.1016/j.enconman.2016.04.061.

[49] J. Liu, Y. Liu, J. Yu, and G. Yan, "Thermodynamic analysis of a novel ejector-enhanced auto-cascade refrigeration cycle," Appl. Therm. Eng., vol. 200, no. October 2021, p. 117636, 2022, doi: 10.1016/j.applthermaleng.2021.117636.

[50] T. Bai, G. Yan, and J. Yu, "Experimental investigation on the concentration distribution behaviors of mixture in an ejector enhanced auto-cascade refrigeration system," Int. J. Refrig., vol. 99, pp. 145-152, Mar. 2019, doi: 10.1016/J.IJREFRIG.2018.11.024.

[51] G. Yan, C. He, and J. Yu, "Theoretical investigation on the performance of a modified refrigeration cycle using binary zeotropic hydrocarbon mixture R170/R290," Int. J. Refrig., vol. 94, pp. 111-117, 2018, doi: 10.1016/j.ijrefrig.2018.07.023.

[52] T. Bai, G. Yan, and J. Yu, "Experimental investigation of an ejector-enhanced auto-cascade refrigeration system," Appl. Therm. Eng., vol. 129, pp. 792-801, Jan. 2018 , 10.1016/J.APPLTHERMALENG.2017.10.053.

[53] X. Hao, L. Wang, Z. Wang, Y. Tan, and X. Yan, "Hybrid auto-cascade refrigeration system coupled with a heat-driven ejector cooling cycle," Energy, vol. 161, pp. 988-998, Oct. 2018, doi: 10.1016/J.ENERGY.2018.07.201.

[54] Y. Tan, L. Wang, and K. Liang, "Thermodynamic performance of an auto-cascade ejector refrigeration cycle with mixed refrigerant R32+R236fa," Appl. Therm. Eng., vol. 84, pp. 268-275, Jun. 2015, doi: 10.1016/J.APPLTHERMALENG.2015.03.047.

[55] K. Du, S. Zhang, W. Xu, and X. Niu, "A study on the cycle characteristics of an auto-cascade refrigeration system," Exp. Therm. Fluid Sci., vol. 33, no. 2, pp. 240245, 2009, doi: 10.1016/j.expthermflusci.2008.08.006.

[56] S. G. Kim and M. S. Kim, "Experiment and simulation on the performance of an autocascade refrigeration system using carbon dioxide as a refrigerant," Int. J. Refrig., vol. 25, no. 8, pp. 1093-1101, 2002, doi: 10.1016/S0140-7007(01)00110-4.

[57] J. S. Oh, M. Binns, S. Park, and J. K. Kim, "Improving the energy efficiency of industrial refrigeration systems," Energy, vol. 112, pp. 826-835, 2016, doi: 10.1016/j.energy.2016.06.119.

[58] S. A. Klein, "Engineering Equaiton Solver(EES).” FChart Software, p. 9.0, 2012.

[59] Q. Jiang et al., "Experimental study on the thermal hydraulic performance of plate-fin heat exchangers for 
cryogenic applications," Cryogenics (Guildf)., vol. 91, pp. 58-67, Apr. 2018, doi: 10.1016/J.CRYOGENICS.2018.02.006.

[60] V. Jain, A. Singhal, G. Sachdeva, and S. S. Kachhwaha, "Advanced exergy analysis and risk estimation of novel $\mathrm{NH} 3-\mathrm{H} 2 \mathrm{O}$ and $\mathrm{H} 2 \mathrm{O}-\mathrm{LiBr}$ integrated vapor absorption refrigeration system," Energy Convers. Manag., vol. 224, no. June, p. 113348, 2020, doi: 10.1016/j.enconman.2020.113348.

[61] V. Jain, G. Sachdeva, and S. S. Kachhwaha, "Comparative performance study and advanced exergy analysis of novel vapor compression-absorption integrated refrigeration system," Energy Convers. Manag., vol. 172, no. June, pp. 81-97, 2018, doi: 10.1016/j.enconman.2018.06.116.

[62] E. Mancuhan, "Comparative evaluation of a two-stage refrigeration system with flash intercooling using different refrigerants," Therm. Sci., vol. 24, no. 2, pp. 815-830, 2020, doi: 10.2298/TSCI180921011M.

[63] T. A. Moreira, F. J. do Nascimento, and G. Ribatski, "An investigation of the effect of nanoparticle composition and dimension on the heat transfer coefficient during flow boiling of aqueous nanofluids in small diameter channels (1.1 mm)," Exp. Therm. Fluid Sci., vol. 89, pp. 72-89, Dec. 2017, doi: 10.1016/J.EXPTHERMFLUSCI.2017.07.020. 